\title{
Study on the Influence Path of Brand Virtual Community Interaction on Customer Loyalty
}

\author{
Shupan Wang, Jinhua Tong, Danting Zhou \\ School of Business Administration, South China University of Technology, Guangzhou, China \\ Email:37152228@qq.com
}

Received 17 December 2015; accepted 22 January 2016; published 25 January 2016

Copyright (C) 2016 by authors and Scientific Research Publishing Inc.

This work is licensed under the Creative Commons Attribution International License (CC BY). http://creativecommons.org/licenses/by/4.0/

(c) (i) Open Access

\begin{abstract}
Virtual brand community is developed based on network technology and has become the theoretical and academic research focus. Interaction in the virtual brand community has a major impact on customer loyalty. This paper studied the impact mechanism on the impacts of the network interaction in virtual community on customer loyalty. The results revealed that the different dimensions, including the two-way communication, customer participation and cooperation of interaction in virtual brand community, have a significant positive relationship with customer perceived value. Then, customer perceived value positively affected trust and customer loyalty and trust had a significant positive impact on customer loyalty.
\end{abstract}

\section{Keywords}

Virtual Brand Community, Network Interaction, Customer Loyalty

\section{Introduction}

With the popularity of the Internet, commercial increasingly competes. With the development of information technology, the network virtual community has become a venue for consumer exchange, discussion and entertainment, while meeting multi-level business needs. It is also one of the most influential and efficient business models (Annstrong \& Agel, 1996) [1]. Therefore, many well-known companies, such as Apple, Dell, Harley, Lenovo etc., established virtual communities of their own brands.

In academic, the commercial value and the potential role of virtual brand community resulted in a hot concern. It is gradually becoming the frontier research in marketing. Scholars studied mainly the mechanism of virtual brand community. However, the vital role of virtual brand community is network interaction. At the same time, many studies showed that the virtual brand community had a positive impact on consumer behavior (Fournier \& Lee, 2009) [2]. However, the effects of network interaction on customer wishes and actions are not investigated. 
Customer loyalty is the research focus in consumer behavior. Therefore, this paper intends to study the impact of virtual brand community interaction on customer loyalty and explore the influential path of virtual brand community interaction on consumer behavior. The results help virtual brand community carry out management practices.

\section{Literature Review and Hypothesis}

\subsection{Related Definitions}

An important form of virtual community, virtual brand community, should be focused and discussed (Algesheimer et al., 2005) [3]. By studying the two virtual brand communities, Canon and Nikon, Abdelmajid \& Lionel (2004) found that virtual brand community is a kind of network space room to be developed to share information among consumers with the same interests by a group of in-depth understanding of a particular brand of consumers (Abdelmajid \& Lionel, 2004) [4]. Consumers share resources through network interaction, enhance the community's sense of identity and honor, form a community with the specific contents, cultures and rules, and ultimately establish a virtual brand community. In this paper, virtual brand community is defined as a kind of a virtual community where a group of people with interest in the same brand carry out uninterruptedly social interaction in a network environment.

Interaction is the key element of the virtual brand community. Interaction is the ability to respond quickly to the people in the mutual communication process, exchanged relations and play the role (Rice \& Love, 1987) [5]. Domestic and foreign scholars carried out extensive research on the definition and dimension of interaction. The research object of this study is virtual brand community, which is initiated and established by the relevant business community. The interaction between a community organizer and members can be equated to that between businesses and consumers. Therefore, in this study, the virtual brand community interaction refers to the interaction between businesses and consumers. Hence, this study used definition and dimension of interaction by Bonner (2003), namely two-way communication, customer participation, and joint solution (Bonner, 2003) [6].

Since 1990, the academic study of customer perceived value were investigated comprehensively. Based on the customer's perspective, customer perceived value refers to an evaluation of the product or service, and the relative value between the perceived benefit and the cost. Customer perceived value consisted of four different elements, including money paid by the customer, the benefits obtained from the products or services, the quality of products or services and the return for customers (Zeithaml, 1988) [7].

Trust is the core element of modern business activities (Wang \& Chen, 2013) [8] and has become a hot research discussion in the Internet context. Scholars from their respective areas define and investigate trust, however, the definition of trust did not reach an agreement. There are different definitions of trust under different situations. The definition of Internet Trust by Mcknight and Kacmar (2002) adopted in this paper is that trust can help customers overcome the perception of risk and uncertainty, and thus participate in network transactions by sharing personal information and purchasing online (Mcknight \& Kacmar, 2002) [9]. The empirical studies showed that trust has a positive predictive impact on the consumer's satisfaction and behavior in the Internet context (Hong \& Cho, 2011) [10].

Customer loyalty has attracted the attention of scholars. The studies found that the cost of developing a new customer is far more than that of maintaining an old customer costs for companies and improving customer loyalty will increase the probability of re-purchasing in the future (Reichheld \& Dawkins, 1990) [11]. The behavior that the customer committed to re-purchase the product or service will not be blocked by enterprise external factors (Oliver, 1999) [12].

\subsection{The Effect of Virtual Brand Community Interaction on Customer Perceived Value}

This study supported the method of categorizing interaction that in Bonner (2003) studied the impact of the interaction between enterprises and customers on new product development and performance, that is interaction consisting of three dimensions: two-way communication, customer participation, jointly solution. The role of two-way communication is to weigh the degree of two-way interaction between community organizers and customers. Customer participation refers to that during the process of buying a product or service, the customer pay time costs, energy costs, search for the desired product or service information and obtain work cognitive, so as to exchange and share information between enterprises. Jointly solution in interaction community refers to a 
collaboration relationship between the customer and community organizer (Bonner, 2003) [6]. This method of categorizing interaction reflects the features of sharing information mutual influence between the two interaction sides. Interaction should be customer-oriented, effectively meet customer demand, excavate and enrich the interaction way and substance between enterprise and customer, and then take a series of initiatives to enhance the feelings between enterprises and customers. Flint et al. (1997) assumed that the customer perceived value is the estimated value. After weighing the resulting benefits and costs of consumption in a particular scene, customers get value judgments and estimates from business (Flint et al., 1997) [13]. Interpersonal theory is that customers can feel the goodwill and respect from the interaction with the enterprise. Enterprises and customers learn and interact from each other and customers participate in enterprises' value creation during interaction (Payne et al. 2008) [14]. Enterprises pay attention to the views or ideas expressed by the customers, which make the customers feel happy and satisfied. In addition, Wei and Yang (2011) studied the impacts of interaction between business and customer on brand trust, and verified that three dimensions, including the company-customer two-way communication, customer participation and joint solution, have a positive effect on the perceived value (Wei \& Yang, 2011) [15]. Furthermore, some scholars proved that the customer perceived value will be affected by a two-way interaction and synchronization in online retail (Yoo \& Lee, 2010) [16]. The interactions not only increases the value and utility of consumers, but also satisfy the customer high-level needs, such as self-realization and respect needs, so this conclusion applies not only online, but also for offline service or other areas. Based on this, the following hypotheses are proposed:

- H1: virtual brand community interaction has a positive impact on customer perceived value;

- H1a: two-way communication has a positive impact on customer perceived value;

- H1b: customer participation has a positive impact on customer perceived value;

- H1c: joint solution has a positive impact on customer perceived value.

\subsection{The Effect of Trust on the Customer Loyalty}

Oliver (1999) defined loyalty as the inherent tendency and commitment to product or service (commitment) and not to change behaviors affected by the external environment and marketing activities. However, Moglant and Hunt's studies showed that loyalty affected commitment (Moglant \& Hunt's, 1994) [17]. Trust is beneficial to forming and maintaining customer loyalty (Reichheld et al., 2000) [18]. Chaudhuri and Holbrook (2001) verified the significant positive correlation between brand trust and customer loyalty (Chaudhuri \& Holbrook, 2001) [19]. Once consumers develop confidence in shopping websites, they will produce identity in their hearts, and take the initiative to maintain relationship with the shopping websites. Chen et al. (2009) studied Taobao and eBay, and found that with the increase of interaction between members of the association, the trust of the members will be transferred to that to the platform, and eventually lead to the loyalty of the members to the platform (Chen et al., 2009) [20]. Pizzutti and Fernandes (2010) points out that to win the trust of consumers is to win consumer loyalty and the most important factor to lead to repeat purchases and positive approvals in the spread (Pizzutti \& Fernandes, 2010) [21]. Moreover, Cyr (2008) studied online consumers in China, Germany and Canada, and found that the impact of the Internet trust to the loyalty is significant in China (Cyr, 2008) [22]. Therefore, this paper presents the hypothesis H3: trust has a positive impact on customer loyalty.

\subsection{The Effect of Trust on the Customer Perceived Value}

The relationship between customer perceived value and trust may be well explained from social exchange theory.

Social exchange theory was founded by Homans in the 1960s, and widely accepted in the behaviorism social psychology theory. This theory assumed that certain types of interactive activities leading to rewards dominated human behaviors, that is the purpose for that humans beings do something is rewarding, and all social activities are attributed to exchanges. In the social exchange theory, people can exchange six kinds of resources, including love, status, information, money, goods and services. Customers can both receive substantial support from the company, and also get emotional support such as care, love and so on. Moreover, when the other side rewards, this social behavior generates for exchange. However, when the other stops rewarding, the social behavior will abort (Blau, 1964) [23]. Based on this, when customers get value from their enterprises, customers will form a willingness to return their enterprises. High perceived value means that customers perceived that the benefits outweigh the costs in this exchange process. Hence, in addition to the payment, customers may also be more 
confidence in the company. This paper presents the hypothesis H3: customer perceived value has a positive effect on trust.

\subsection{The Relationship between the Customer Perceived Value and the Customer Loyalty}

Jones et al. (1995) pointed out that the customer perceived value played a key role in the customer satisfaction experience and attitude loyalty. In order to achieve lasting and effective customer satisfaction and customer loyalty, it is necessary to provide superior customer value (Jones et al., 1995) [24]. The higher the customer perceived value, the higher the customer satisfaction with the product. In the future customers are willing to choose the company and the loyalty to the company is improved (Cronin et al., 1997) [25]. Cronin et al. (1997) believed that the customer loyalty is the primary factor to affect the customer perceived value (Cronin et al., 1997) [26]. Woodruff (1997) found that high perceived value of customers will bring high satisfaction with the products and the customers are likely to choose the enterprise in the future and has a higher loyalty to the enterprise (Woodruff, 1997) [27]. Based on customer value-customer loyalty model, Blackwell et al. (1999) proposed that profits perception, perceived loss of profit, situational and personal preferences affect the perceived value, and perceived value and context have a positive impact on customer loyalty (Blackwell et al., 1999) [28]. This paper presents the hypothesis H4: customer perceived value has a positive impact on customer loyalty.

\section{Methodology}

\subsection{The Sample and Data Collection}

In this paper, convenience sampling method is adopted. Since the investigation subjects of this paper are the network users in virtual brand community, questionnaires are distributed through online networks. In this paper, online networks are distributed by two ways: firstly, the questionnaire are distributed using instant messaging software QQ or sending e-mail links to various types of consumers, and finally back to the specified mailbox; secondly, the questionnaire are published through questionnaires websites and filled their members. Through these two methods, a total of 261 questionnaires are returned. Excluding questionnaires that are not filled completely and unreasonable invalid questionnaires, there are 230 valid questionnaires and the questionnaires efficiency is $88.1 \%$. Among them, the number of male sample is 119 , accounting for $52 \%$. The respondents below 29 years accounted for $75 \%$. The respondents with a degree of bachelor degree and above accounted for $96 \%$. A sample of students and company employees accounted for about $40 \%$.

\subsection{Questionnaire Structure and Variable Measurements}

Based on the questionnaire design proposed by Li Huaizu (2004), since the subjects of this study are the users who have contact with and a certain understanding of virtual brand community, the characteristics of these users are taken into account when designing questionnaires. Through reviewing literature on the research related variables, as well as understanding the meaning of each variable, the appropriate measurement scale was used to the preliminary design of the questionnaire. In this paper, the questionnaire is divided into three parts:

The first is the preface, mainly to clarify the background, the purposes and contents of the study, and set questionnaire situations, so that consumers remember their own experience based on research purposes, which is as a basis for evaluation scoring.

The second is the questions of this study, including measuring different research variables: virtual brand community interaction, customer perceived value, trust and customer loyalty and allowing users to rate their own actual situation.

The last is the subject basic information, including gender, age, education level, the time registered as a member of the community, the average numbers of visiting per week, the average time spent per visit.

Measurement scale used in this study is a Likert fifth scale. Measurement scales of virtual brand community interaction are mainly modified based on that developed by Mohr and Nevin (1990) [29], which consists of three dimensions, two-way communication, customer participation and joint resolution, and a total of nine questions. Measurement scale of virtual brand community interaction is composed by four questions, based on the study by Eggert and Ulaga (2002) [30]. The measure of trust refers to the study by McAllister (1995) [31], including six questions. Measurement scale of customer loyalty is from that developed by Ganesh et al. (2000) [32], including 5 questions. 


\section{Results Analysis}

\subsection{Reliability and Validity Analysis}

This paper carried out a reliability test using the software SPSS. The results are shown in Table 1 . For three dimensions in virtual brand community interaction, customer perceived value, trust and customer loyalty, Cronbach's $\alpha$ are above 0.7 . Therefore, the measurement scale is reliable.

The results of exploratory factor analysis showed that KMO values of the four variables Scale were greater than 0.5 . The variables are significant and suitable for factor analysis. The factor load value of the questions related to community interaction and trust are greater than 0.5 and significant cross-loads are identified. Therefore, dimensions of variables can be distinguished. For customer perceived value and customer loyalty, only one factor is produced, and the one-dimensional variable research setting is satisfied. Therefore, the use of measurement scales satisfied the requirements of construct validity.

\subsection{Correlation Analysis}

As shown in Table 2, the three dimensions of the virtual brand community interaction are positively related to customer perceived value. Among them, the correlation coefficients between customer perceived value and trust, and customer loyalty were 0.624 and 0.582 , respectively. The correlation coefficient between trust and customer loyalty is 0.688 . Therefore, they have a significant positive correlation.

Table 1. Reliability and validity analysis.

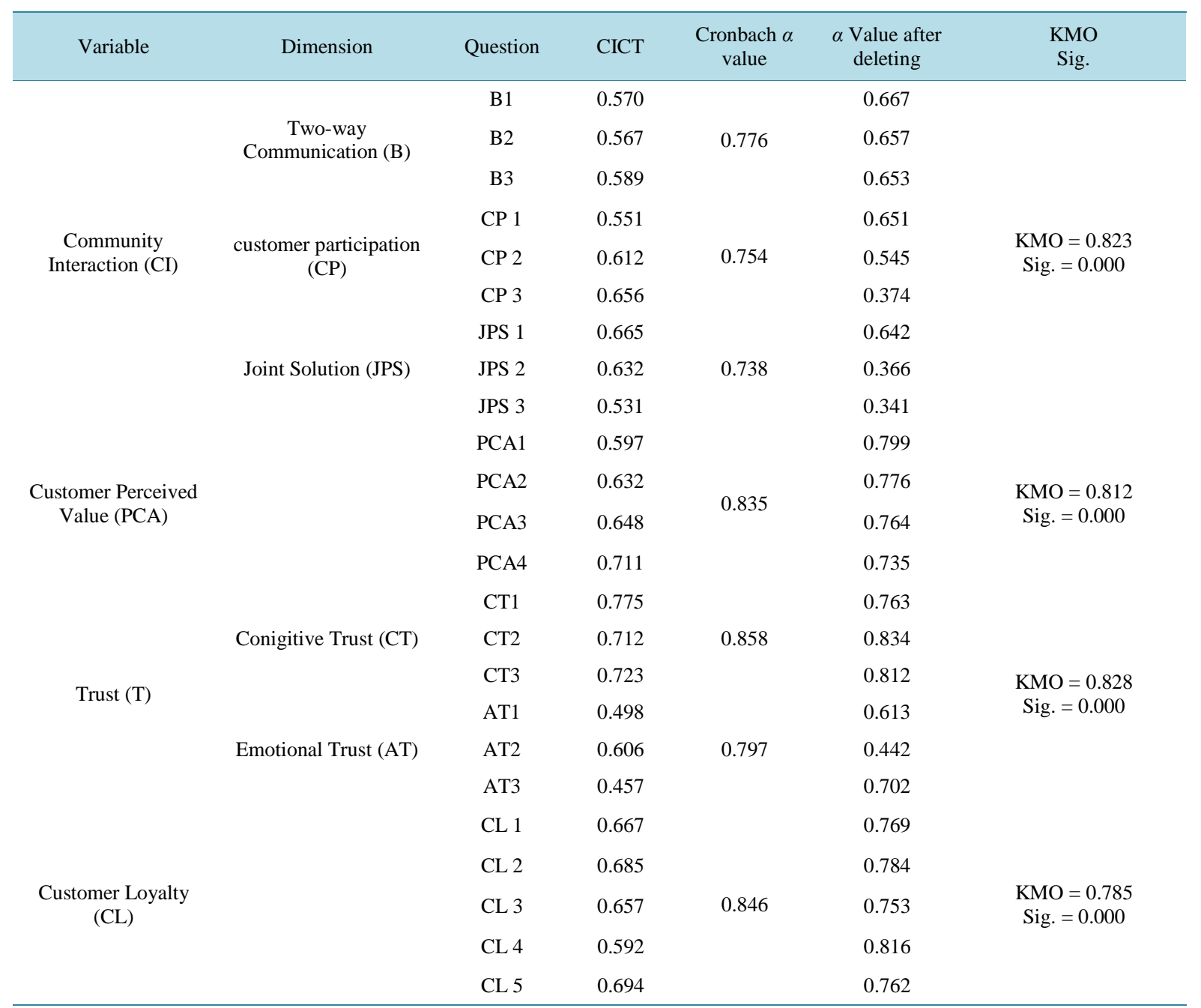


Table 2. The results of correlation analysis of variables.

\begin{tabular}{|c|c|c|c|c|c|c|}
\hline & 1 & 2 & 3 & 4 & 5 & 6 \\
\hline 1) Community interaction & 1 & - & - & - & - & - \\
\hline 2) Two-way communication & $0.737^{* *}$ & 1 & - & - & - & - \\
\hline 3) Custermor participation & $0.729^{* *}$ & $0.261^{* *}$ & 1 & - & - & - \\
\hline 4) Joint Solution & $0.723^{* *}$ & $0.336^{* *}$ & $0.313^{* *}$ & 1 & - & - \\
\hline 5) Customer perceived value & $0.534^{* *}$ & $0.531^{* *}$ & $0.525^{* *}$ & $0.381^{* *}$ & 1 & - \\
\hline 6) Trust & $0.387^{* *}$ & $0.359^{* *}$ & $0.411^{* *}$ & $0.384^{* *}$ & $0.624^{* *}$ & 1 \\
\hline 7) Custermor & $0.461^{* *}$ & $0.359^{* *}$ & $0.328^{* *}$ & $0.291^{* *}$ & $0.582^{* *}$ & $0.688^{* *}$ \\
\hline
\end{tabular}

${ }^{* *} \mathrm{p}<0.01, \stackrel{*}{\mathrm{p}}<0.05$.

\subsection{Structural Equation Model Analysis}

In this paper, structural equation hypothesis testing and the sample data statistical analysis using the software, AMOS17.0. In the model, each standardized factor loading volume is between 0.4 to 0.9 , and reached the significant level. Fit indices are as follows: $\chi^{2} / \mathrm{df}=2.513$, GFI $=0.927$, RMR $=0.031$ less than 0.05 , RMSEA $=$ 0.069 less than 0.08; AGFI $=0.821$, NFI $=0.935$, CFI $=0.911$ greater than 0.8 ; PNFI $=0.765$, PCFI $=0.848$ greater than 0.05 . Fitting index values are in line with the requirements, which indicated that model fit of the theoretical model is well. According to the above hypothesis testing, Table 3 is as follows.

\section{Discussions}

\subsection{The Effects of Each Dimension in Community Interaction on the Customer Perceived Value}

The results showed that hypothesis H1a is supported, that is two-way communication in community interaction has a direct significant positive impact on customer perceived value. The role of two-way communication in community interaction is to measure the degree of two-way interaction between community organizers and customers. On one hand, the consumers passively absorb and accept the business promotion, advertising, articles and related products and other information in the virtual brand community. On the other hand, consumers will also actively seek and collect the required information and data, such as product purchasing experience, trial experience, etc. In addition, consumers will take the initiative to help enterprises spread and recommend these information to others (Zhang et al., 2011) [33], or provide comments or suggestions to the community organizer or business. In the process of both passive and active behaviors, two-way interaction will strengthen the customer value perception to the enterprise.

Meanwhile, the study showed that the hypothesis H1b is supported, that is customer participation in the community has a direct significant positive impact on customer perceived value. Customer participation refers to that during the process of buying a product or service, the customer pay time costs, energy costs, search for the desired product or service information and obtain work cognitive, so as to exchange and share information between enterprises. (Ennew \& Binks, 1999) [34]. Customers participate in product-related activities organized by the virtual brand community, such as product trial, experience and other services, and thus become more familiar with the enterprise. Consumers participate in the process of service, which allows companies to fully understand the needs of individual consumers, and make consumers more familiar with their roles and the whole process of the service. Thus, the effects of service are more accurate and reasonable expectations, and the possibility of unsatisfactory service could be reduced, so as to enhance the customer perception value to the enterprise. In addition, mutual communications among different customers will help to strengthen the team cooperation and community identity of customers. Moreover, the customer perception value to the enterprise is also improved.

Finally, the study showed that, the hypothesis H1c is supported, that is community interaction joint solution has a direct significant positive impact on customer perceived value. Joint solution in interaction community refers to a collaboration relationship between the customer and community organizer, and mainly jointly solves and improves problems during new products trial and customer experiences. Joint solution between the customer 
Table 3. Results summary of hypothesis testing.

\begin{tabular}{cccc}
\hline No. & Relationship among variables & Hypothesis & Testing results \\
\hline 1 & Community interaction $\rightarrow$ Customer perceived value & H1 & Support \\
2 & Two-way communication $\rightarrow$ Customer perceived value & H1a & Support \\
3 & Customer participation $\rightarrow$ Customer perceived value & H1b & Support \\
4 & Joint Solution $\rightarrow$ Customer perceived value & H1c & Support \\
5 & Trust $\rightarrow$ Customer Loyalty & H2 & Support \\
6 & Customer perceived value $\rightarrow$ Trust & H3 & Support \\
7 & Customer perceived value $\rightarrow$ Customer Loyalty & H4 & Support \\
\hline
\end{tabular}

and the community can enhance the customer control over the behavior of a particular service. It can be explained by attribution theory that customers and communities strengthen the frequency and extent of mutual interaction through jointly solving a specific problem. When common solutions achieve more satisfactory service results, customers will tend to credit to themselves, thereby increasing their satisfaction, and improving customer perception value to the enterprise.

\subsection{The Effects of the Customer Perceived Value and Trust to the Customer Loyalty}

Firstly, the empirical results showed that hypothesize $\mathrm{H} 2$ and $\mathrm{H} 3$ are supported, that is trust has direct significant positive effect on customer loyalty and the customer perceived value on the trust. Social exchange theory assumed that certain types of interactive activities leading to rewards dominated human behaviors, that are the purpose for that human beings do something is rewarding, and all social activities are attributed to exchanges. If one side had a social exchange behavior, the other side in a good position would achieve the commitments and responsibilities in return, which is the basis of "mutual benefits" principle, also known as "the principle of reciprocity." The relationship between people classified as "transaction contract" and "relationship contract". Taken the concept of "contract", "transaction contract" means a contract to comply with during economic exchange in business activities, and "relationship contract" is built on trust of social exchanges. Only based on trust, consumers will believe that after they pay time and energy, a company will give its equivalent in return, producing a series of mutually beneficial behaviors, and thus enhancing customer loyalty to the enterprise.

Secondly, the empirical results showed that, hypothesis $\mathrm{H} 4$ is supported, that is customer perceived value has a significant positive correlation with customer loyalty. However, the impact of the trust on the customer loyal is more direct and significant than that of the customer perceived value. If customers get a relatively high perceived value during service, the loyalty to the enterprises is not obviously enhanced. For example, in virtual brand communities, although a member of the community acquired a higher perceived value during interaction, the probability that the member of the loyalty to the company is increased is not great. This is due to that the contractual relationship between the customer and the business is built after a long enough time. The frequency and number of community interaction may not enough so that customers know and believe the enterprises. During the entire mutually beneficial process, customers do not have enough confidence in the enterprises, showing less loyalty. When the customers have enough confidence in the enterprise, the intent of purchasing the company's products or services in the future will be greater and the loyalty to the enterprises larger.

\subsection{The Effects of Community Interaction on the Customer Loyalty}

From the theoretical model results of this study, it is found that virtual brand community interaction significantly affect customer loyalty through customer perceived value and trust. Virtual brand community interaction does not play a direct linear impact on customer loyalty, through changing and strengthening some intermediate variables. Community interaction not only allows enterprises to understand the consumer, but also consumers to be familiar with the enterprise. In the process of interaction, the strangeness with each other is eliminated, and the distance between the two sides becomes close. The role of interaction is to excite the customer in interaction with each other, resulting in a series of psychological changes. The psychological changes include the formation of new intentions and behaviors, that is the virtual brand community interaction will influence the mentality of 
customers, and then the formation of customer loyalty. In this study, when building the relationship model between virtual brand community interaction and customer loyalty, two variables, customer perceived value and trust, are set as the bridge between community interaction and customer loyalty. Through these two mediating variables, the impacts of community interaction on customer loyalty have been investigated. The results showed that in an interaction process in virtual brand community, customers can improve the perceived value to the enterprise, and thus provide stable and lasting trust to the enterprise. The intention to buy the company's products or services in the future is greater and purchase behaviors are more positive, so the customer loyalty to the enterprise is also higher.

\section{Enlightenments and Future Work}

\subsection{Enlightenments}

The results showed that under the intermediary role influences of customer perceived value and trust, virtual brand community interaction will affect the customer loyalty. Enterprises can start to strengthen virtual brand community interaction, resulting in manage efficiently customer relationship in virtual brand community.

1) To improve the interaction platform and strengthen the two-way interaction

Construction measures of interaction platform include developing and strengthening the usefulness and usability of the website. To select more smoothly Web browsing improves the smoothness. In addition, it is necessary to carefully layout the website page and do profile aesthetically, and content should be sufficient and reasonable. Hence, community members find quickly information what they needs. For real-time services, there must be an efficient online customer service. It is necessary to be more proactive to exchange with customers, thereby strengthen the customer goodwill to community and business.

2) To establish and improve the incentive mechanism and improve customer participation

Enterprises can establish an effective incentive mechanism to improve the willingness of customer participation, including material rewards (such as product promotions, discounts, rewards, etc.) and spiritual incentive honors. The results in this study showed that, compared with two-way communication and joint solution, customer participation has a more significant impact on customer perceived value. Spiritual incentive honors help improve customer participation, therefore, companies can pay attention to and strengthen the spiritual incentive honors to improve customer loyalty.

3) To deal with rapidly and efficiently customer complaints and pay attention to customers' comments and suggestions

The study found that community interaction and joint resolution have a positive relationship with customer perceived value, which indicating that to solve jointly problems by customers and communities can effectively improve the customer perceived value. If customers' issues are timely and effectively solved, and paid enough attention to, companies can acquire more confidence of customers.

\subsection{Limitations and Future Work}

In this study, there are still some limitations. Firstly, due to the limitations of human and financial resources, we distributed questionnaires in a non-random manner. There may be sampling errors on the data and the universality of the results should be verified in the future. Secondly, the model contains only two mediating variables: the customer perceived value and trust. Other intermediary paths will be explored in the future.

\section{Acknowledgements}

Thanks to the fund support by the National Social Science Fund Youth Project (12CGL036).

\section{References}

[1] Annstrong, A. and Hagel, J. (1996) The Real Value of Online Communities. Harvard Business Review, 74, $134-141$.

[2] Fournier, S. and Lee, L. (2009) Getting Brand Communities Right. Harvard Business Review, 87, 105-111.

[3] Algesheimer, R., Dholakia, U.M. and Herrmann, A. (2005) The Social Influence of Brand Community: Evidence from European Car Clubs. Journal of Marketing, 69, 19-34. http://dx.doi.org/10.1509/jmkg.69.3.19.66363

[4] Amine, A. and Sitz, L. (2004) How Does a Virtual Brand Community Emerge? Some Implications for Marketing Re- 
search. Research Paper.

[5] Rice, R. and Love, G. (1987) Electronic Emotion: Socioemotional Content in a Computer-Mediated Communication Network. Communication Research, 85-108.

[6] Bonner, J.M. (2010) Customer Interactivity and New Product Performance: Moderating Effects of Product Newness and Product Embeddedness. Industrial Marketing Management, 39, 485-492. http://dx.doi.org/10.1016/j.indmarman.2008.11.006

[7] Zeithaml, V.A. (1998) Consumer Perceptions of Price, Quality, and Value: A Means-End Model and Synthesis of Evidence. Journal of Marketing, 52, 2-22. http://dx.doi.org/10.2307/1251446

[8] Wang, W. and Chen, R. (2013) A Review of the Literature of Trust on the Internet and Prospects. Foreign Economics \& Management, 10, 52-61.

[9] Mcknight, D.H. and Kacmar, C. (2002) Developing and Validating Trust Measures for e-Commerce: An Integrative Typology. Information Systems Research, 13, 334-359. http://dx.doi.org/10.1287/isre.13.3.334.81

[10] Hong, I.B. and Cho, H. (2011) The Impact of Consumer Trust on Attitudinal Loyalty and Purchase Intentions in B2C e-Marketplaces: Intermediary Trust vs. Seller Trust. International Journal of Information Management, 31, 469-479. http://dx.doi.org/10.1016/j.ijinfomgt.2011.02.001

[11] Reichheld, F.F. and Dawkins, P.M. (1990) Customer Retention as a Competitive Weapon. Directors Broads, 14, 4247.

[12] Oliver, R.L. (1999) Whence Consumer Loyalty? Journal of Marketing, 63, 33-44. http://dx.doi.org/10.2307/1252099

[13] Flint, D.J., Woodruff, R.B. and Gardial, S.F. (2002) Exploring the Phenomenon of Customers’ Desired Value Change in a Business-to-Business Context. Journal of Marketing, 66, 102-117. http://dx.doi.org/10.1509/jmkg.66.4.102.18517

[14] Payne, A.F.,Storbacka, K. and Frow, P. (2008) Managing the Co-Creation of Value. Journal of the Academy of Marketing Science, 36, 83-96. http://dx.doi.org/10.1007/s11747-007-0070-0

[15] Wei. H.Y. and Yang, G.L. (2011) An Analysis on the Effects of the Interaction between Company and Customer on Brand Trust. Finance \& Trade Economics, 4, 79-84.

[16] Yoo, W.S. and Lee, Y. (2010) The Role of Interactivityine-Talking: Creating Value and Increasing Satisfaction. Journal of Retailing and Consumer Services, 2, 89-96. http://dx.doi.org/10.1016/j.jretconser.2009.10.003

[17] Morgan, R.M. and Hunt, S.D. (1994) The Commitment-Trust Theory of Relationship Marketing. Journal of Marketing, 58, 20-38. http://dx.doi.org/10.2307/1252308

[18] Reichheld, F.F. and Schefter, P.E. (2000) Loyalty: Your Secret Weapon on the Web. Harvard Business Review, 78.

[19] Chaudhuri, A. and Holbrook, M.B. (2001) The Chain of Effects from Brand Trust and Brand Affect to Brand Performance: The Role of Brand Loyalty. Journal of Marketing, 65, 81-93. http://dx.doi.org/10.1509/jmkg.65.2.81.18255

[20] Chen, J., Zhang, C. and Xu, Y. (2009) The Role of Mutual Trust in Building Members’ Loyalty to a C2C Platform Provider. International Journal of Electronic Commerce, 14, 147-171. http://dx.doi.org/10.2753/JEC1086-4415140105

[21] Pizzutti, C. and Fernandes, D. (2010) Effect of Recovery Efforts on Consumer Trust and Loyalty in E-Tail: A Contingency Model. International Journal of Electronic Commerce, 14, 127-160. http://dx.doi.org/10.2753/JEC1086-4415140405

[22] Cyr, D. (2008) Modeling Web Site Design across Cultures: Relationships to Trust, Satisfaction, and E-Loyalty. Journal of Management Information Systems, 24, 47-72. http://dx.doi.org/10.2753/MIS0742-1222240402

[23] Blau, P.M. (1964) Exchange and Power in Social Life. Wiley, New York.

[24] Jones, T.O. and Earl Jr., S.W. (1995) Why Satisfied Customers Defected. Harvard Business Review, 24, 88-99.

[25] Woodruff, R.B. (1997) Customer Value: The Next Source for Competitive Advantage. Journal of the Academy of Marketing Science, 25, 139-153. http://dx.doi.org/10.1007/BF02894350

[26] Cronin, J.J., Brady, M.K., Brand, R.R., Hightower, J. and Shemwell, D.J. (1997) A Cross-Sectional Test of the Effect and Conceptualization of Service Value. Journal of Services Marketing, 11, 375-391. http://dx.doi.org/10.1108/08876049710187482

[27] Woodruff, R.B. (1997) Customer Value: The Next Source for Competitive Advantage. Journal of the Academy of Marketing Science, 25, 139-153. http://dx.doi.org/10.1007/BF02894350

[28] Blackwell, S.A., Szeinbach, S.L., Barnes, J.H., Garner, D.W. and Bush, V. (1999) The Antecedents of Customer Loyalty: An Empirical Investigation of the Role of Personal and Situational Aspects on Repurchase Decisions. Journal of Service Research, 1, 362-375. http://dx.doi.org/10.1177/109467059914007

[29] Mohr, J. and Nevin, R. (1990) Communication Strategies in Marketing Channels: A Theoretical Perspective. Journal of Marketing, 54, 36-51. http://dx.doi.org/10.2307/1251758 
[30] Eggert, A. and Ulega, W. (2002) Customer Perceived Value: A Substitute for Satisfaction in Business Markets. Journal of Business and Industrial Marketing, 17, 107-118. http://dx.doi.org/10.1108/08858620210419754

[31] McAllister, D.J. (1995) Affect- and Cognition-Based Trust as Foundations for Interpersonal Cooperation in Organizations. Academy of Management Journal, 38, 24-59. http://dx.doi.org/10.2307/256727

[32] Ganesh, J., Arnold, M.J. and Reynolds, K.E. (2000) Understanding the Customer Base of Service Providers: An Examination of the Differences between Switchers and Stayers. Journal of Marketing, 64, 65-87. http://dx.doi.org/10.1509/jmkg.64.3.65.18028

[33] Zhang, H., Wang, T. and Liu, H.S. (2011) Why Participated Customers Still Dissatisfied Research on the Relationship between the Illusion of Control and Customer Satisfaction in Customer Participation. Nankai Business Review, 14, 153-160.

[34] Ennew, C.T. and Binks, M.R. (1999) Impact of Participative Service Relationships on Quality, Satisfaction and Retention: An Exploratory Study. Journal of Business Research, 46, 121-132.

http://dx.doi.org/10.1016/S0148-2963(98)00016-2 